\title{
INTER-FIRM GOVERNANCE AND RELATIONSHIP QUALITY: A STUDY ON 3PL FIRMS
}

\author{
*Aytuğ SÖZÜER \\ *Gültekin ALTUNTAŞ \\ *Fatih SEMERCIÖZ \\ *Istanbul University, Turkey
}

\begin{abstract}
The purpose of this study is to investigate the governance mechanisms as drivers of relationship quality perceived in buyer-supplier exchanges in transportation and logistics industry. The study deals with the question of "what type of governance underlies the inter-firm relationship quality in terms of third party logistics (3PL) firms?”. Thus, the research inquires buyer-supplier relationships from the service providers' perspective. Data are obtained from 216 transportation and logistics firms in Turkey through a crosssectional survey in 2015. Evidence shows that both formal and informal contracts have positive but separate direct effects on the relationship quality and denies a support for the complementarity view. In other words, one type of governance such as detailed agreements or trust is positively related to working relationships; however their combined presence does not necessarily produce a high quality relationship. The study is expected to contribute to the extant literature on relationship quality antecedents by investigating a prominent construct, i.e., relationship governance in a less explored logistics services context. Furthermore, research findings can shed light on customer relationship management issues in service industry, especially for third party logistics firms.
\end{abstract}

Keywords: Inter-firm governance, relationship quality, transportation and logistics providers

\section{INTRODUCTION}

Inter-organizational relationships are the links and ongoing transactions between two or more organizations (Oliver, 1990). In management literature, cooperative inter-organizational relationships are expressed as inter-firm relationships or alliances, after it becomes obvious that business transactions evolve into relationships over time (Ritter \& Gemünden, 2003). Cooperation between firms describes the strong and extensive social, economic, and technological ties in pursuit of efficiency and value creation (Anderson \& Narus, 1991). Eventually, productive and long-lasting relationships become a source of competitive advantage (Dyer \& Singh, 1998; Ganesan, 1994; Morgan \& Hunt, 1999). Those ties also define a distinct level of analysis for management and organization research (Coase, 1937; Williamson, 1979).

Inter-firm relationships, even though with cooperative intentions, are not free of obstacles. Since each side pursues its own interests, conflicts may naturally happen on occasion. There is a cost of maintaining a relationship and organizations need to put effort, time, and capital to foster it (Ritter \& Gemünden, 2003). Consequently, there is an atmosphere reflecting the expectations and modes of power-dependence, distanceproximity, and cooperation-conflict among partners in every relationship (Hakansson, 1982). One way to describe and assess such an atmosphere is the relationship quality (Crosby et al., 1990).

Inter-firm relationship quality has become a popular construct in business marketing, which has gained empirical endeavor (see Athanasopoulou, 2009; Leonidou et al., 2014; Vieira et al., 2008 for comprehensive reviews). Basically, the relationship quality reflects "the overall depth and climate in the inter-firm relationships" (Johnson, 1999) and "the caliber of relational ties between exchange partners that influence or restrain a partner's actions” (Palmatier, 2008). The construct is highly relevant to services setting where both the exchanges and the relational outcomes are intangible.

Despite being a young industry overall, transportation and logistics (TL) services in Turkey has made significant progress in recent years (PWC, 2006). First of all, looking at macro level, GDP per capita increased by $43 \%$ in Turkey from year 2000 to the end of 2013 (in constant prices; TurkStat, 2015). In the same period, Turkish companies increased country's share in world merchandise trade by $75 \%$. TL industry 
also followed this growth path, which is especially facilitated by automotive, iron \& steel, and textile industries. Eventually, Turkey's ranking has gone up between 2010 and 2014 from 39th to 30th in the International Logistics Performance Index 2014, scoring $80 \%$ of the highest performer, due to the improved infrastructure, border procedures, and service quality (TWB, 2014). Furthermore, Turkey is ranked 10th in the Emerging Markets Logistics Index in terms of market attractiveness and connectedness, owing to the country's geographical configuration as a major trade corridor between Europe, Asia, and Africa (Agility, 2014). Fierce competition between the market players, both domestic and international, is also a driver of the industry's dynamism. Besides, privatization process of transport infrastructure such as ports, highways, bridges, etc. appears as another key trend for the following decade (PWC, 2006). However, there's the other side of the coin. Although there's a growth potential of TL industry in Turkey, very few enterprises are fully professionalized (KUGM, 2013). Moreover, high price sensitive market leaves little room to service providers for innovation and technology investments. Within this context, efficient customer relationship management seems to be high on the agenda of third party logistics firms.

Given that the emergence of TL industry, little is known about the drivers of inter-firm relationship success in terms of logistics services providers (Chu \& Wang, 2012). Although there is an exhaustive literature on governance and relationship quality constructs, this study tries to address them in an under explored context. Theoretically, the study supports that the level of inter-firm governance is positively related to the relationship quality, however refutes the argument that combined mechanisms are more productive. Moreover, it is likely that the research has managerial implications, especially for decision making on governance in regard to customer relationship management in TL sector

The following sections will first frame the relevant literature and develop the hypotheses, then define the research methodology and present the findings of data analysis, and lastly conclude with a brief discussion.

\section{CONCEPTUAL BACKGROUND AND HYPOTHESES}

\section{Relationship Quality}

As relationship quality refers to the strength and atmosphere of the relational ties between exchange partners, it is generally acknowledged as a higher-order construct composed of several dimensions. In her review, Athanasopoulou (2009) notes the pioneer studies of relationship quality as Dwyer \& Oh (1987), Crosby et al. (1990), and the stream gaining momentum afterwards. Holmlund (2001) defines relationship quality as "the joint cognitive evaluation of business interactions by key individuals in the dyad, comparative to the alternative exchanges". There are many other conceptualizations in literature, however, Woo \& Ennew (2004) suggest that relationship quality should be accepted as a general reflection and studies would better focus on the construct dimensions within particular contexts. In regard, Lages et al. (2005) identified information sharing, communication quality, long-term orientation, and satisfaction as the indicators of relationship quality in their scale development study. Another scale was proposed by Mysen \& Svensson (2010) composed of commitment, competitive intensity, continuity, cooperation, dependence, formalization, market turbulence, opportunism, specific assets, and trust constructs. Likewise, the relationship quality scale by Payan et al. (2010) identified cooperation, coordination, specific assets, satisfaction, trust, and commitment dimensions. Considering several other variations in literature and the specific settings of this study, we take satisfaction, commitment, cooperation, and communication as the dimensions of relationship quality.

Satisfaction refers to a firm's overall positive evaluation of an ongoing relationship with another firm (Dwyer et al., 1987). Commitment signifies a firm's willingness to maintain a working relationship with its partner as the firm finds that very important (Morgan \& Hunt, 1994). Cooperation is "the coordinated actions of firms to achieve mutual goals" (Anderson \& Narus, 1990). Communication can be defined as "the formal and informal sharing of meaningful and timely information between firms” (Anderson \& Narus, 1984). Taken together; satisfaction, commitment, cooperation, and communication would be the proxies for mutual gains and future transactions of the dyad (Nyaga \& Whipple, 2011). Therefore, high relationship quality can be characterized by high levels of satisfaction, commitment, cooperation, and communication among firms.

Similar to its conceptualization, the research on the determinants of relationship quality construct is inconclusive as well. Athanasopoulou (2009) classifies the antecedents of relationship quality into four major 
Journal of Global Strategic Management | V. 9 | N. 1 | 2015-June | isma.info | 31-42| DOI: 10.20460/JGSM.2015915626 groups: 1) the characteristics of the firms; 2) the characteristics of the relationship; 3) the transactional properties; and 4) the environmental circumstances. The research interest of this study can be attributed to the second group. Within that category, extant literature investigated formal contracts (e.g. Burkert et al., 2012; Cannon \& Perreault, 1999; Genctürk \& Aulakh, 2007); relational norms (e.g. Ivens, 2005; Zhang et al., 2003); transaction-specific investments (e.g. Poppo et al., 2008; Zaheer \& Venkatraman, 1995); and relationship time (e.g. Aulakh \& Genctürk, 2008; Poppo \& Zenger, 2002) as the drivers of relationship quality dimensions in various contexts. Reviewing the individual constructs, we infer that it is likely to understand most of them within a broader concept, i.e., inter-firm governance.

\section{Inter-firm Governance \& Relationship Quality}

Governance reflects the formal and informal mechanisms that regulate inter-firm exchanges. Distinct from the traditional modes of market and hierarchy, the intermediate forms of governance became more relevant in repeated business transactions (Zaheer \& Venkatraman, 1995). Transaction cost economics (Williamson, 1979) and relational exchanges (Macneil, 1980) are the two mainstream theoretical perspectives that capture those intermediate modes of governance, which are often expressed on a transactional-relational continuum. Although these transactional and relational terms are typical, the dual mechanism is also referred as hard and soft, explicit and normative, formal and informal or written and unwritten contracts by researchers (Ferguson et al., 2005). Thus, contractual governance (or hard, explicit, formal, and written contracts) reflects the formalization of the inter-firm exchanges and relational governance (or soft, normative, informal, and unwritten contracts) signifies the social norms that regulate the relationship.

In transaction cost economics perspective, well drafted contracts are proposed to avoid opportunism in case of high behavioral uncertainty (Williamson, 1979). Formal contracts are said to provide a relational order, in which the roles and tasks of the parties, as well as the remedies for contingencies are clearly defined (Poppo \& Zenger, 2002). On the other hand, it is argued that, informal contracts also have the potential to prevent opportunism or enhance adaptability to changing conditions (Macneil, 1980). Relational mechanisms that are not bound with strict norms could also work due to the mutual understanding of the partners and their goodwill to maintain the relationship (Noordewier et al., 1990). So, the literature offers two perspectives for inter-firm governance, each with distinct theoretical underpinnings (Gençtürk \& Aulakh, 2007). However, co-existence of multiple mechanisms in organizations is also acknowledged and coined as plural forms (Bradach \& Eccles, 1989). In respect, we find it plausible to investigate formal and informal mechanisms as separate but not opposite facets of inter-firm governance in this study. Based on extant governance literature, we take contract formalization and transaction specific investments as the formal arrangements; trust and contract flexibility as the informal mechanisms, which can have potential direct and interaction effects on relationship quality.

According to transaction cost economics, a formal contract is the fundamental inter-firm governance mechanism (Williamson, 1985). Formalization refers to "the extent to which detailed and binding contractual agreements are used to specify the roles and the obligations of the parties” (Cannon et al., 2000). The basic assumption is that if the relationship is regulated with explicit contracts, specific rules and procedures, parties would know what they should expect from each other in the future (Mysen \& Svensson, 2010). Moreover, legal contracts can include safeguards and sanctions to restrict the parties behaving opportunistically. So, the formal contracts help stabilizing the relationship. However, previous research shows the degree of formalization can have positive or negative effects on the relationship outcomes (Mysen \& Svensson, 2010).

As mentioned in the first part, TL is a young industry in Turkey and professional standards have not fully developed yet. Therefore, contract formalization can be the major mechanism in relationship governance. In a similar context, the study of Chu \& Wang (2012) on Chinese logistics outsourcing firms indicates a legal contract is positively related to relationship quality, although marginally.

Transaction-specific investments (TSI) refer to the assets such as personnel and equipment dedicated by a firm to a particular relationship, which has considerably less value outside that relationship (Heide \& John, 1990). Eventually, large TSI makes it costly to exit that relationship (Kang et al., 2013). And whenever the relationship is at difficulty, dedicated assets pose hazards if unassisted by specific formal arrangements (Williamson, 1985). So, it would be necessary to formalize the governance in order to safeguard the special investments (Heide \& John, 1992). Furthermore, TSI can appear as pledges in a relationship (Anderson \& 
Weitz 1992). That's why, we view TSI as a part of formal governance mechanisms. On the other hand, dedicated assets to a relationship signal a long-term orientation and foster commitment (Anderson \& Weitz 1992). They also increase interdependence, which in turn lead to partners' cooperative engagement in order to make the relationship as successful as possible (Zacharia et al., 2009). So, it's plausible to expect TSI yields favorable outcomes in a relationship. In regard to this reasoning, we predict;

Hypothesis 1. In a business relationship, the higher the level of formal governance such as (a) contract formalization and (b) transaction- specific investments, the higher is the relationship quality.

Trust in an exchange relationship relates to the partners' perception of credibility and benevolence for each other (Ganesan, 1994). In a trusting relationship, one party believes that the other party is reliable to fulfill its promises (Dwyer et al., 1987). Trust is regarded as a major factor to develop a long-term relationship (Anderson \& Weitz, 1989) since it tends to strengthen a future orientation (Burkert et al., 2012). On the other hand, low or lack of trust in a relationship is very likely to stimulate unfavorable attitudes and hence negative results (Dwyer et al., 1987; Lenonidou et al., 2013). Regarding trust as a significant constituent of a relational exchange (Macneil, 1980), it is highly logical that this informal mechanism leads to satisfaction in a relationship (Çerri, 2012).

Another critical relational norm in a business relationship is the flexibility. It reflects a bilateral expectation of willingness to make rearrangements as conditions change (Heide \& John, 1992). In long-term exchanges, the environment surrounding the relationship may differ drastically at times and the formal agreements between partners may not be adequate (Thompson, 1967). So, the agreements can be subject to modification if one party confronts difficulties due to new situations (Zhang et al., 2003). Flexibility is highly crucial in a service-setting, as timing is very important because the output cannot be stored. Lack of flexibility or one firm's strict bound on formal contracts may decrease the relationship value for the other party when support is necessary (Ivens, 2005). In line with this thinking, Bello \& Gilliland (1997) find a positive relationship between flexibility and industrial channel performance and Ivens (2005) provides evidence for the flexibility as the driver of relationship quality in services context. In respect to above arguments, we posit;

Hypothesis 2. In a business relationship, the higher the informal governance such as (a) trust and (b) contract flexibility, the higher is the relationship quality.

Although some prominent scholars (e.g. Dyer \& Singh, 1998; Williamson, 1985) view formal and informal governance mechanisms as a dichotomy; some others (e.g. Bradach \& Eccles, 1989; Cannon et al., 2000) argue their simultaneous or combined use is possible and can be more productive. The first perspective claims that relational mechanisms decrease the need for contract formalization and financial pledges, thus reducing the transaction costs (Çavuşgil et al., 2004). The latter defends that when sudden changes happen, which could not be foreseen by formal agreements, relational mechanisms would ensure the stability of the relationship (Poppo \& Zenger, 2002). However, empirical evidence is inconclusive about these opposing views. Several studies reveal that formal and informal arrangements function as complements for positive relationship outcomes (Poppo \& Zenger, 2002; Stump \& Heide, 1996); some others cannot find significant support for this effect (Çavuşgil et al., 2004; Nevins \& Money, 2008). In pursuit of an empirical explanation for this discussion, we suggest;

Hypothesis 3. In a business relationship, combined presence of formal and informal mechanisms as in contract formalization and trust together increases the relationship quality.

The conceptual model of the study is presented in Figure 1. 


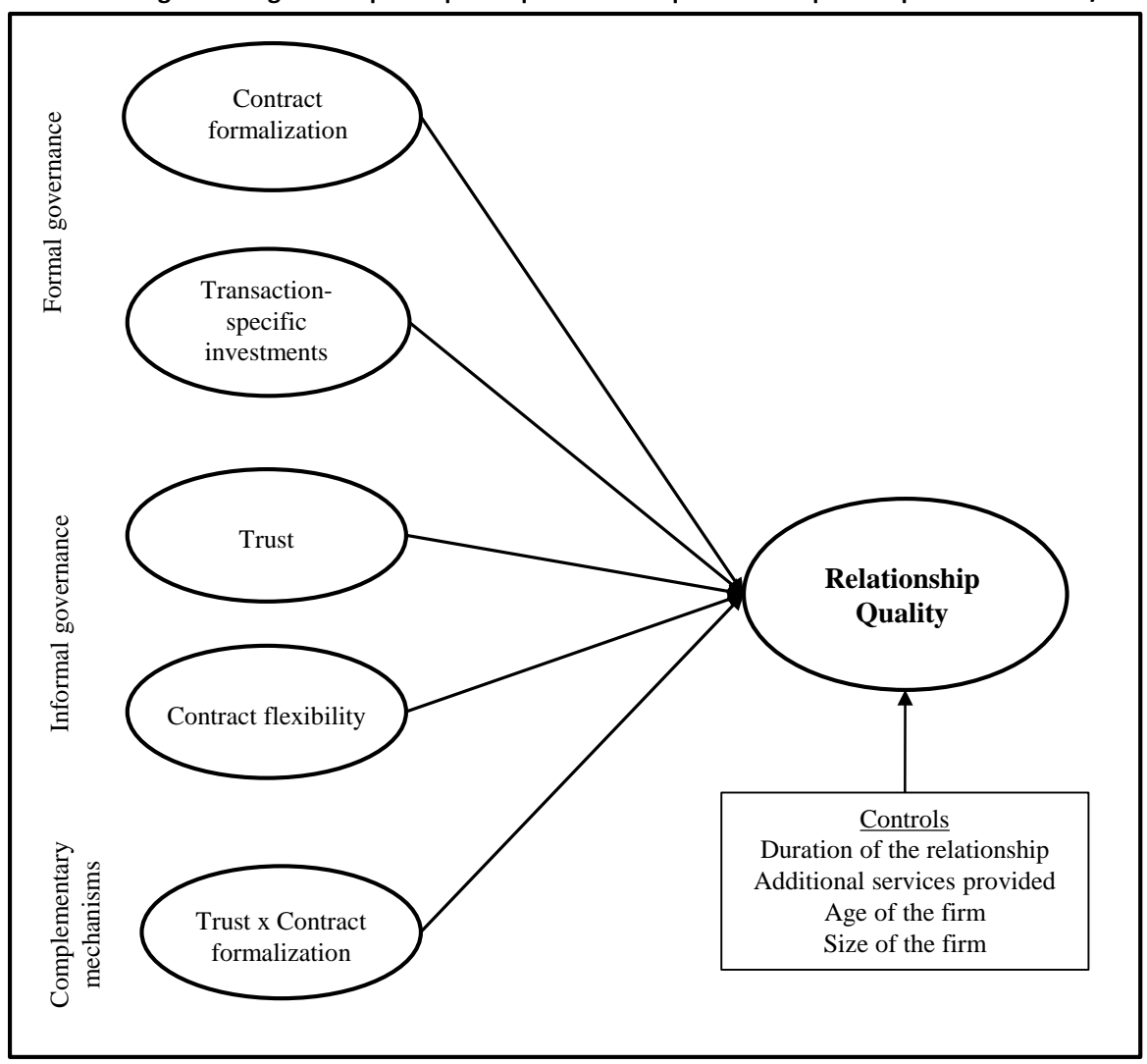

Figure 1. The research model

\section{METHODOLOGY}

\section{Sample and Data Collection}

International Transporters Association is the biggest professional organization in land transportation services industry in Turkey, representing 90\% of the market, as declared (UND, 2015). It had 1184 registered members when the research started in January 2015. We randomly contacted 500 firms from the members' directory of which 236 accepted to join the survey through telephone. The data collection took a month approximately. After filtering very small and very large firms (having less than 10 or more than 250 employees), we ended up with 216 usable cases.

The age of firms varied from 2 to 85 years with a median of 15 years. The median number of employees was 34. 150 firms (69\%) operated only in land transportation whereas others provided air and/or sea transportation services as well. 9 firms (4\%) provided only domestic transportation and the rest also handled export/import carriage. 15 firms (7\%) had foreign equity.

The organizational positions of the key informants were either $(1)$ a general manager or equivalent $(\approx 26 \%)$, (2) a manager who directly reported to the highest ranked executive $(\approx 45 \%)$ or $(3)$ a manager or a specialist who reported to the level 2 manager $(\approx 29 \%)$. We also asked respondents to indicate how much they were confident with their answers in per cents and the average score was around $84 \%$.

\section{Measures}

Relationship quality is conceptualized as consisting satisfaction, commitment, cooperation, and communication dimensions, so we adapted relevant items from literature to measure the construct. We included five items from Fierro \& Redondo (2011); four items from Leonidou et al. (2013); two items from Chinomona (2013); and one item from Kang et al. (2013) in our questionnaire. Contract formalization construct is measured by adapting the three-item scale developed by Cannon and Perreault (1999). Transaction-specific investments measure is consisted of two items from Nyaga \& Whipple (2011) and one 
item from Kang et al. (2013). Trust is measured by adapting three items from Leonidou et al. (2013) and one item from Fierro \& Redondo (2011). Contract flexibility is measured by using three items from relational norms scale in Kang et al. (2013).

All above scales were operationalized with five-point Likert-type responses such as " 1 = strongly disagree”, “5 = strongly agree”.

The research model included four control variables, namely the duration of the relationship, the additional services provided to the customer, the age, and the size of the firm. These controls were measured as follows: (i) duration of the relationship is the number of years since the transactions started, (ii) additional services such as customs and/or insurance brokerage provided to the customer defined a dummy variable coded as "1" if so and as "0" if not, (iii) age of the firm is the number of years since the firm's foundation, and (iv) size of the firm is the number of its employees. These are included to control whether longer and deeper relationships reflect higher perceptions of relationship quality and whether larger and more mature firms can sustain better business relationships.

Since all the measurement items were translated from English language, three management academicians and two foreign trade specialists examined the scale to address face and content validity as well as wording flow and clarity.

\section{Analyses and Findings}

For preliminary tests, item-total correlations, measure of internal consistency, and exploratory factor analysis (maximum likelihood estimation) were conducted. Several items were dropped from the scale to purify the construct measures. Besides, five items from four projected dimensions of relationship quality loaded into a single factor. This made us to continue analyses by acknowledging the relationship quality as a unidimensional construct, which is not a rare conceptualization (e.g. Çerri, 2012; Johnson, 1999; Kim et al., 2011). Confirmatory factor analysis (CFA) was applied to validate the measurement model. The model showed acceptable fit to the data $\left(\chi_{(63)}^{2}=96.79 ; \mathrm{p}<0.01 ; \chi 2 / \mathrm{df}=1.54 ; \mathrm{TLI}=0.96 ; \mathrm{CFI}=0.97 ; \mathrm{RMSEA}=0.50\right.$; PCLOSE=0.48). The outputs are presented in Table 2.

Construct means, standard deviations, and correlations are presented in Table 1. The largest correlation coefficient among independent variables appeared as 0.61 .

Table 1. Descriptive statistics and inter-construct correlations

\begin{tabular}{llllllllll}
\hline Constructs & 1 & 2 & 3 & 4 & 5 & 6 & 7 & 8 & 9 \\
\hline 1. Contract formalization & 1 & & & & & & & & \\
2. Transaction-specific investments & .07 & 1 & & & & & & & \\
3. Trust & $.43^{* *}$ & .03 & 1 & & & & & & \\
4. Contract flexibility & $.28^{* *}$ & .11 & $.33^{* *}$ & 1 & & & & & \\
5. Relationship quality & $.42^{* *}$ & $.26^{* *}$ & $.61^{* *}$ & $.39^{* *}$ & 1 & & & & \\
6. Duration of the relationship & .03 & $.15^{*}$ & .12 & .13 & .12 & 1 & & & \\
7. Additional services provided & -.09 & .08 & -.11 & -.07 & -.10 & .13 & 1 & & \\
8. Age of the firm & $.16^{*}$ & .08 & .06 & -.02 & .02 & $.48^{* *}$ & .06 & 1 & \\
9. Size of the firm & .11 & .09 & .08 & -.05 & .05 & $.23^{* *}$ & .12 & .38 & 1 \\
Mean & 4.38 & 3.44 & 4.33 & 3.94 & 4.59 & 10.01 & .32 & 17.26 & 44.66 \\
SD & .77 & 1.23 & .72 & .99 & .51 & 6.76 & .47 & 11.84 & 38.29 \\
\hline
\end{tabular}

** Correlation is significant at the 0.01 level (2-tailed)

* Correlation is significant at the 0.05 level (2-tailed)

Note: Latent factors are the unweighted means of the items for each construct.

For reliability measures, Cronbach's alpha $(\alpha)$ and composite reliability (CR) coefficients were satisfactory except the contract flexibility factor $(\alpha=0.63$; $C R=0.65)$, which were slightly lower than the regular threshold of .70. That might be acceptable considering that the latent variable was measured with only 2 items. In regard to the convergent validity, the standardized loadings of each item measuring the relevant factor and their average variances extracted (AVE) were above 0.5 . The only exception was again the contract 
Journal of Global Strategic Management | V. 9 | N. 1 | 2015-June | isma.info | 31-42| DOI: 10.20460/JGSM.2015915626 flexibility construct (AVE=0.49), which was short only marginally. However, the convergent validity of constructs was found acceptable at this level. Furthermore, it was confirmed that the square root of each construct's AVE was greater than inter-construct correlations to ensure the discriminant validity (Fornell \& Larcker, 1981).

Given that data were collected from a single informant of each organization, common method bias issue was addressed by Harman's single factor test (Podsakoff et al., 2003), which extracted 35\% of variance on a single factor. It suggested that a substantial common method bias was unlikely.

Table 2. Measurement model

\begin{tabular}{|c|c|c|}
\hline Construct $^{a}$ & Loadings $^{b}$ & $t$-values ${ }^{b}$ \\
\hline \multicolumn{3}{|l|}{ Relationship quality $(\alpha=0.88 ; C R=0.88 ; A V E=0.59)^{c}$} \\
\hline Overall, the relationship with our customer is satisfactory. & 0.83 & 14.17 \\
\hline We think that our customer is a good company to do business with. & 0.77 & 12.84 \\
\hline Exchange of information wtih our customer is direct and informal. & 0.67 & 10.32 \\
\hline We solve potential problems with our customer cooperatively. & 0.81 & 13.86 \\
\hline We are very committed to the relationship with our customer. & 0.75 & 11.97 \\
\hline \multicolumn{3}{|l|}{ Contract formalization $(\alpha=0.70 ; C R=0.71 ; A V E=0.56)$} \\
\hline $\begin{array}{l}\text { We have detailed agreements with our customer that clearly specify } \\
\text { the obligations of both parties. }\end{array}$ & 0.65 & 8.61 \\
\hline $\begin{array}{l}\text { We have customized contracts with our customer in order to } \\
\text { resolve unexpected situations. }\end{array}$ & 0.83 & 10.36 \\
\hline \multicolumn{3}{|l|}{ Transaction-specific investments $(\alpha=0.81 ; C R=0.85 ; A V E=0.75)$} \\
\hline customer. & 0.67 & 7.30 \\
\hline $\begin{array}{l}\text { We have made special investments in equipment or support systems } \\
\text { dedicated to our customer. }\end{array}$ & 1.02 & 8.76 \\
\hline \multicolumn{3}{|l|}{ Trust $(\alpha=0.78 ; C R=0.84 ; A V E=0.64)$} \\
\hline Our customer is a trustworthy company. & 0.90 & 14.56 \\
\hline Our customer always its keeps promises to us. & 0.75 & 12.00 \\
\hline Our customer does not behave us opportunistically. & 0.73 & 10.47 \\
\hline \multicolumn{3}{|l|}{ Contract flexibility $(\alpha=0.63 ; C R=0.65 ; A V E=0.49)$} \\
\hline $\begin{array}{l}\text { We are flexible in changing the contract articles in case our } \\
\text { customer has any difficulty. }\end{array}$ & 0.80 & 8.65 \\
\hline $\begin{array}{l}\text { We can rearrange the agreement with our customer in case our } \\
\text { customer has any difficulty. }\end{array}$ & 0.58 & 7.12 \\
\hline \multicolumn{3}{|l|}{$\begin{array}{l}\text { Goodness-of-fit statistics: } \chi^{2}{ }_{(63)}=96.79 ; p<0.01 ; \chi^{2} / \mathrm{df}=1.54 ; \\
\text { TLI }=0.96 ; \mathrm{CFI}=0.97 ; \mathrm{RMSEA}=0.50 ; \text { PCLOSE }=0.48\end{array}$} \\
\hline \multicolumn{3}{|l|}{${ }^{a}$ Construct variances are fixed to set the scale. } \\
\hline${ }^{\mathrm{b}}$ Loadings are from standardized, $t$-values are from unstandardized & . & \\
\hline
\end{tabular}

For hypothesis testing, hierarchical multiple regression analysis (ordinary least squares) was used. In order to overcome the potential multicollinearity issues for the interaction terms, we mean-centered the independent variables before the analysis. Collinearity diagnostics showed variance inflation factor (VIF) scores less than 2, suggesting the model did not suffer from multicollinearity. Table 3 shows the regression results. 
Table 3. Hierarchical multiple regression results

\begin{tabular}{|c|c|c|c|c|}
\hline \multirow[t]{2}{*}{ Independent variables } & \multicolumn{4}{|c|}{$\begin{array}{l}\text { Dependent variable } \\
\text { Relationship quality }\end{array}$} \\
\hline & Model 1 & Model 2 & Model 3 & Model 4 \\
\hline \multicolumn{5}{|l|}{ Control variables } \\
\hline Duration of the relationship & $.15^{* * *}(1.91)$ & $.14 * *(1.98)$ & $.04(.67)$ & $.04(.59)$ \\
\hline Additional services provided & $-.13 * * *(-1.82)$ & $-.10(-1.55)$ & $-.05(-.88)$ & $-.04(-.77)$ \\
\hline Age of the firm & $-.06(-.74)$ & $-.12 * * *(-1.70)$ & $-.06(-1.04)$ & $-.06(-1.02)$ \\
\hline Size of the firm & $.05(.69)$ & $.01(.11)$ & $-.00(-.02)$ & $.00(-.00)$ \\
\hline \multicolumn{5}{|l|}{ Direct effects } \\
\hline Contract formalization & & $.41 *(6.73)$ & $.17 *(2.92)$ & $.18 *(2.92)$ \\
\hline Transaction-specific investments & & $.23 *(3.76)$ & $.22 *(4.32)$ & $.22 *(4.26)$ \\
\hline Trust & & & $.47 *(8.21)$ & $.48 *(8.20)$ \\
\hline Contract flexibility & & & $.15 *(2.72)$ & $.15^{*}(2.74)$ \\
\hline \multicolumn{5}{|l|}{ Interaction effect } \\
\hline Contract formalization $\mathrm{x}$ Trust & & & & $.03(.55)$ \\
\hline$R^{2}$ & .03 & .26 & .48 & .48 \\
\hline Adjusted $R^{2}$ & .01 & .24 & .46 & .46 \\
\hline$F$ & 1.68 & $11.98^{*}$ & $23.96 *$ & $21.26^{*}$ \\
\hline$R^{2}$ change & & $.23^{*}$ & $.22 *$ & .00 \\
\hline$F$ change & & $31.61 *$ & $44.83 *$ & .30 \\
\hline
\end{tabular}

Model 1 consisted the control variables. It appeared that duration of the relationship and the additional services provided had marginal and weak effects on relationship quality $(\mathrm{p}<0.1)$. When formal governance mechanisms were entered for Model 2, R-square changed by .23 $(\mathrm{p}<0.01)$ and the standardized coefficients of contract formalization and transaction-specific investments were .41 and .23 ( $p<0.01$ ) consecutively. Further, in Model 3, informal governance mechanisms were entered and R-square again changed by .22 ( $<$ < 0.01). The standardized coefficients of trust and contract flexibility were .47 and .15 ( $p<0.01)$, decreasing the former independent variables' coefficients to .17 and $.22(\mathrm{p}<0.01)$ respectively. Meanwhile, the coefficients of control variables became insignificant. Adjusted R-square of the model was .46. Model 4 included the final set of constructs in order to test the interaction effect of contract formalization and trust on relationship quality. However, no significant change occurred in this last model and the interaction term's effect was marginal and insignificant. In sum, Hypotheses 1(a), 1(b), 2(a), and 2(b) were supported but Hypothesis 3 was rejected. The results will be discussed briefly in the final section.

\section{SUMMARY AND CONCLUSION}

Based on inter-firm governance literature, we examined the effects of formal and informal mechanisms on relationship quality in the scope of transportation and logistics industry. Developed conceptual model was tested using a survey data from third party logistics firms in Turkey. Findings suggested that the level of governance mechanisms is positively related to the relationship quality. Contract formalization and transaction-specific investments on one side; trust and contract flexibility on the other side showed significant direct effects on the perceived quality of ongoing inter-firm exchanges. The logical link between trust and flexibility with good relationships can be obvious. The empirical research also supports this premise (Anderson \& Weitz, 1989; Ivens, 2005). However, the relationship outcomes of the degree of formal governance are not straightforward according to previous studies (Mysen \& Svensson, 2010). One theoretical contribution of this research is revealing the positive effects of higher levels formal arrangements on the relationship quality. Naturally, this argument is contingent on a young service industry in Turkey where industry standards and professionalism are newly developing. Moreover, this study contributes to the 
discussion of substitutes and complementarity views of governance mechanisms. There's contrasting evidence in literature whether the presence of formal and informal contracts function well separately or combined (Poppo \& Zenger, 2002; Çavuşgil et al., 2004). Our study reflects no significant interaction effect of contract formalization and trust on relationship quality. So, the results deny the complementarity view and indicate that formal or informal mechanisms can individually foster inter-firm relationships.

The study suggests several managerial implications as well. First of all, it appears that forms of governance do matter in working relationships within transportation and logistics services context. Managers should be keen on formal or informal contracts with their partners. Regardless of the type, higher levels of governance mechanisms are more likely to produce favorable outcomes. In respect to service providers, a focus should be on the regulation of relationships since our findings show that effective governance is more important than several other attributes such as the relationship duration, the number of services provided to the partner, the age and the size of their firm. Further, managers do not need to be highly sensitive in finding formal and informal arrangements simultaneously as a governance type. Our research reveals either mechanism can work satisfactorily in terms of relationship management.

As a matter of fact, this study is subject to several limitations. The most significant one is that it investigated the relationship quality phenomena from the supplier's perspective. Conceptually, dyadic studies are more relevant in assessing the construct. However, the volume of relationship quality analyses focusing on one side is far more than those, which could survey both parties in literature (Athanasopoulou, 2009). Second, the research estimated governance forms as the driver of relationship quality, whereas further studies should include environment and transaction characteristics in their model. Third, the research was industry specific, so it is hard to generalize the findings to other contexts. The following studies should also make use of personal and in-depth inquires to adapt the measurement scales in respect to their particular research setting.

\section{Acknowledgments}

Authors would like to thank to the Scientific Research Projects (BAP) Office at Istanbul University for the granted research fund in support of this study (Project no: ACIP-50361). 


\section{REFERENCES}

Agility (2014). “Agility emerging markets logistics index 2014”, http://www.agility.com/EN/AboutUs/Documents/Agility\%20Emerging\%20 Markets \%20Logistics\%20Index\%202014.pdf, Access date: 30.03.2015.

Anderson, E., B. Weitz (1989). "Determinants of continuity in conventional industrial channel dyads”, Marketing Science, 8(4): 310-323.

Anderson, J.C., J.A. Narus (1984). “A model of the distributor's perspective of distributor-manufacturer working relationships”, Journal of Marketing, 48: 62.74.

Anderson, J.C.,J.A. Narus (1991). “Partnering as a focused market strategy”, California Management Review, 33(3): 95-113.

Athanasopoulou, P. (2009). "Relationship quality: a critical literature review and research agenda”, European Journal of Marketing, 43(5\&6): 583-610.

Aulakh, P.S., F.E. Genctürk (2008). “Contract formalization and governance of exporter-importer relationships”, Journal of Management Studies, 45: 457-479.

Bello, D.C., D.I. Gilliland, D.I. (1997). "The effect of output controls, process controls, and flexibility on export channel performance”, Journal of Marketing, 61: 22-38.

Bradach, J.L. \& Eccles, R.G. (1989). "Price, authority, and trust: From ideal types to plural forms”, Annual Review of Sociology, 15, 97-118.

Burkert, M. B.S. Ivens, J. Shan (2012). “Governance mechanisms in domestic and international buyersupplier relationships: an empirical study”, Industrial Marketing Management, 41: 544-556.

Cannon, J.P., R.S. Achrol, G.T. Gundlach (2000). “Contracts, norms, and plural forms of governance”, Journal of the Academy of Marketing Science, 28(2): 180-194.

Cannon, J.P., W.D. Perreault JR, (1999). “Buyer-supplier relationships in business markets”, Journal of Marketing Research, 36: 439-460.

Chinomona, R. (2013). “Dealer’s legitimate power and relationship quality in gaunxi distribution channel: A social rule system theory perspective”, International Journal of Marketing Studies, 5(1): 42-58.

Chu, Z., Q. Wang (2012). "Drivers of relationship quality in logistics outsourcing in China”, Journal of Supply Chain Management, 48(3): 78-96.

Coase, R.H. (1937). “The Nature of the Firm”, Economica, 4(16): 386-405.

Crosby, L.A., K.R. Evans, D. Cowles (1990). "Relationship quality in services selling: An interpersonal influence perspective”, Journal of Marketing, 54: 68-81.

Çavuşgil, S.T., S. Deligönül, C. Zhang (2004). "Curbing foreign distributor opportunism: An examination of trust, contracts, and the legal environment in international channel relationships”, Journal of International Marketing, 12(2): 7-27.

Çerri, S. (2012). "Exploring factor affecting trust and relationship quality in a supply chain context”, Journal of Business Studies Quarterly, 4(1): 74-90.

Dwyer, F.R., P.H. Schur, S. Oh (1987). “Developing buyer-seller relationships”, Journal of Marketing, 51: 11-27.

Dwyer, F.R., S. Oh (1987). “Output industry munificence effects on the internal political economy of marketing channels”, Journal of Marketing Research, 24: 347-358.

Dyer, J.H., H. Singh, (1998). “The relational view: cooperative strategy and sources of interorganizational competitive advantage”, The Academy of Management Review, 23(4): 660-679. 
Journal of Global Strategic Management | V. 9 | N. 1 | 2015-June | isma.info | 31-42| DOI: 10.20460/JGSM.2015915626

Ferguson, R.J., M. Paulin, J. Bergeron (2005). “Contractual governance, relational governance, and the performance of interfirm service exchanges: The influence of boundary-spanner closeness”, Journal of the Academy of Marketing Science, 2: 217-234.

Fierro, J.J.C., Y.P. Redondo, (2011). "Post-satisfaction factors affecting the long-term orientation of supply relationships”, Journal of Business \& Industrial Marketing, 26(6): 395-406.

Fornell, C., D.F. Larcker, (1981). "Evaluating structural equation models with unobservable variables and measurement error”, Journal of Marketing Research, 18(1): 39-50.

Ganesan, S. (1994). "Determinants of long-term orientation in buyer-seller relationships”, Journal of Marketing, 58(2): 1-19.

Genctürk, E.F., P.S. Aulakh (2007). “Norms and control-based governance of international manufacturerdistributor relational exchanges”, Journal of International Marketing, 15(1): 92-126.

Hakansson, H. (1982). International Marketing and Purchasing of Industrial Goods: An Interaction Approach, Wiley, New York.

Heide, J.B., G. John (1992). “Do norms matter in marketing relationships?”, Journal of Marketing, 56: 32-44.

Holmlund, M. (2001). “The D\&D model - dimensions and domains of relationship quality”, The Service Industries Journal, 21(3): 13-36.

Ivens, B.S. (2005). "Flexibility in industrial service relationships: the construct, antecedents, and performance outcomes”, Industrial Marketing Management, 34: 566-576.

Johnson, J.L. (1999). "Strategic integration in industrial distribution channels: managing the interfirm relationship as strategic asset”, Journal of the Academy of Marketing Science, 27(1): 4-18.

Kang, B., S. Oh, E. Sivadas (2013). "Beyond relationship quality: Examining relationship management effectiveness”, Journal of Marketing Theory and Practice, 21(3): 273-287.

Kim, D., C. Basu, G.M. Naidu, E. Çavuşgil (2011). "The innovativeness of born-globals and customer orientation: Learnnigfrom Indian born-globals”, Journal of Business Research, 64: 879-886.

KUGM, Directorate General of Road Transport Regulation (2013). "Strengthening combined transport of Turkey”, http://www.kugm.gov.tr/BLSM_WIYS/TMKDG/tr/Mevzuat/Taslaklar/20140606_144029 _64574_1_64896.pdf, Access date: 30.03.2015

Lages, C., C.R. Lages, L.F. Lages (2005). “The RELQUAL scale: a measure of relationship quality in export market ventures”, Journal of Business Research, 58: 1040-1048.

Leonidou, C.N., L.C. Leonidou, D.N. Coudounaris, M. Hultman (2013). "Value differences as determinants of importers' perceptions of exporters' unethical behavior: The impact on relationship quality and performance”, International Business Review, 22: 156-173.

Leonidou, L.C., S. Samiee, B. Akyol, M.A. Talias (2014). “Antecedents and outcomes of exporter-importer relationship quality: Synthesis, meta-analysis, and directions for further research”, Journal of International Marketing, 22(2): 21-46.

Macneil, I.R. (1980). “Power, contract, and the economic model”, Journal of Economic Issues, 14(4): 909923.

Morgan, R.M., S. Hunt (1999). "Relationship-based competitive advantage: The role of relationship marketing in marketing strategy”, Journal of Business Research, 46: 281-290.

Mysen, T., G. Svensson (2012). "RELQUAL's impact on satisfaction in Norwegian business relationships”, Journal of Business and Industrial Marketing, 25(2): 119-131.

Nevins J.L., R.B. Money, (2008). "Performance implications of distributor effectiveness, trust, and culture in import channels of distribution”, Industrial Marketing Management, 37: 46-58.

Noordewier, T.G., G. John, J.R. Nevin (1990). "Performance outcomes of purchasing arrangements in industrial buyer-vendor relationships”, Journal of Marketing, October: 80-93. 
Nyaga, G.N., J.M. Whipple (2011). "Relationship quality and performance outcomes: achieving a sustainable competitive advantage”, Journal of Business Logistics, 32(4): 345-360.

Oliver, C. (1990). "Determinants of interorganizational relationships: Integration and future directions”, Academy of Management Journal, 15(2): 241-265.

Palmatier, R.W. (2008). “Interfirm relational drivers of customer value”, Journal of Marketing, 72: 76-89.

Payan, J.M., G. Svensson, G. Awuah, S. Andersson, J. Hair (2010). "A “cross-cultural RELQUAL-scale” in supplier-distributor relationships of Sweden and the USA", International Marketing Review, 27(5): 541 561.

Podsakoff, P.M., S.B. MacKenzie, J-Y. Lee, N.P. Podsakoff (2003). "Common method bias in behavioral research: A critical review of the literature and recommended remedies”, Journal of Applied Psychology, 88(5): 879-903.

Poppo, L., K.Z. Zhou, T.R. Zenger (2008). "Examining the conditional limits of relational governance: specialized assets, performance ambiguity, and long-standing ties”, Journal of Management Studies, 45: 1195-1216.

Poppo, L., T. Zenger (2002). "Do formal contracts and relational governance function as substitutes or complements?”, Strategic Management Journal, 23: 707-725.

PWC, PriceWaterhouseCoopers (2006). “Transportation \& Logistics 2030”, http://www.pwc.com /en_GX/gx/transportation-logistics/tl2030/emerging-markets/pdf/tl2030_vol3_final.pdf, Access date: 30.03.2015

Ritter, T., H.G. Gemünden (2003). “Interorganizational Relationships and Networks: An overview”, Journal of Business Research, 56(9): 691-697.

Stump, R.L., J.B. Heide (1996). “Controlling supplier opportunism in industrial relationships”, Journal of Marketing Research, 23: 431-441.

Thompson, J. D. (1967). Organizations in Action, New York; McGraw-Hill.

TurkStat, Turkish Statistical Institute (2015). "Main Statistics, National Accounts”, http://www.turkstat.gov.tr, Access date: 30:03.2015.

TWB, The World Bank (2014). “Connecting to compete, trade logistics in the global economy”, http://www.worldbank.org/content/dam/Worldbank/document/Trade/LPI2014.pdf, Access date: 30:03.2015.

Vieira, A.L., H. Winklhofer, C.T. Ennew, (2008). "Relationship quality: A literature review and research agenda”, Journal of Customer Behaviour, 7 (4): 269-291.

Williamson, O.E. (1979). “Transaction-cost economics: the governance of contractual relations”, Journal of Law and Economics, 22(2): 233-261.

Williamson, O.E. (1985). The Economic Institutions of Capitalism: Firms, Markets, Relational Contracting, New York: The Free Press.

Woo, K., C.T. Ennew (2004). “Business-to-business relationship quality: An IMP interaction-based conceptualization and measurement”, European Journal of Marketing, 38(9/10): 1252-1271.

Zacharia, Z.G., N.W. Nix, R.F. Lusch (2009). “An analysis of supply chain collaborations and their effect on performance outcomes”, Journal of Business Logistics, 30(2): 101 -123.

Zaheer, A., N. Venkatraman (1995). "Relational governance as an interorganizational strategy: an empirical test of the role of trust in economic exchange”, Strategic Management Journal, 16: 373-392.

Zhang, C., S.T. Çavuşgil, A.S. Roath (2003). "Manufacturer governance of foreign distributor relationships: do relational norms enhance competitiveness in the export market?”, Journal of International Business

Studies, 34: 550-566. 